\title{
A CONSTRUÇÃO DA MULHER NOS CONTOS MARAVILHOSOS: UM OLHAR SOBRE AS ORIGENS DO CLÁSSICO INFANTO-JUVENIL PARA COMPREENDER O CONTEMPORÂNEO
}

\section{THE CONSTRUCTION OF WOMEN IN MARVELOUS SHORT STORIES: FROM THE ORIGINS OF CHILDREN'S AND JUVENILE STORIES UP TO CONTEMPORARY NARRATIVES}

\author{
Maria Aparecida Saraiva Magalhães de Sousa \\ Liane Schneideri
}

RESUMO: Este trabalho tem como objetivo lançar um olhar sobre os estudos em torno das origens e desenvolvimento dos contos maravilhosos, de modo a verificar como se deu a construção da imagem da mulher em tais produções, buscando observar as alterações sofridas ao longo dos tempos, para chegar à compreensão do contemporâneo através da discussão de um dos contos de Marina Colasanti (1994), no caso, "A moça tecelã". Tomamos como base, especialmente, o "rastreamento" de cunho histórico-cultural apresentado por Nelly Novaes Coelho (2010) acerca da Literatura Infanto-Juvenil, bem como as reflexões de Maria Emília Traça (1992), tecidas a partir de um viés sociológico e antropológico, que vão do conto popular ao conto para crianças. Entremeado a esse estudo, buscamos fundamentação nos pressupostos teóricos dos estudos culturais e de gênero, como forma de problematizar as inevitáveis questões que surgem ao se tratar de tal temática.

PALAVRAS-CHAVE: A imagem da mulher. Elementos mágicos. Literatura infantojuvenil.

ABSTRACT: This paper aims to analyze studies on the origins and development of children's and adolescent's stories in which the magical element is present, verifying the way the image of women has been constructed in such literary context. Beginning with historical discussions supported by Nelly Novaes Coelho (2010) on this kind of writing and with sociological and anthropological reviews developed by Maria Emília Traça (1992), our study aims to get to the analysis of a short story by Marina Colassanti (1994), in case, "A moça tecelã", so to exemplify the discussed topics. Our literary criticism is based on theoretical foundations of cultural and gender studies, perspectives from where we construct the questions we pose and the answers we present.

KEYWORDS: Women's image. Magical elements. Children and adolescent literature.

Submetido em: 09 abr. 2018.

Aprovado em: 30 nov. 2018.

\footnotetext{
' Doutoranda do Programa de Pós-Graduação em Letras da Universidade Federal da Paraíba.

E-mail:maria_asms@hotmail.com.

ii Universidade Federal da Paraíba. E-mail: schliane@gmail.com. 
É inegável que a maioria das pessoas possui uma memória afetiva das narrativas orais e dos contos de fadas que povoaram suas vivências/experiências desde a mais tenra idade. Longe de serem coisas do passado, os contos de outrora estão bem presentes no imaginário das crianças e jovens de todos os tempos. Mesmo na era de domínio das novas tecnologias da comunicação e da informação, o que não faltam são novas versões e adaptações dos contos maravilhosos ${ }^{1}$, seja para as novas mídias, seja para novas formas de narrar as histórias antigas aos novos leitores. Em seu livro $O$ Fio da Memória: do Conto Popular ao Conto para Crianças, Maria Emília Traça (1992, p. 23) é categórica ao afirmar: "os contos, sobretudo os contos de fadas, estão na moda, um pouco por todo o lado. Há sinais inequívocos da sua vitalidade. Os contos são formas vivas." No Prefácio à obra citada, Georges Jean defende os Contos Populares como uma forma de "fazer a criança mergulhar de novo numa cultura esquecida e perdida" e de possibilitar que as portas de um outro futuro sejam abertas. Recorrer a essa memória afetiva, acessando o repertório das histórias ouvidas e lidas na infância e adolescência pode representar uma produtiva forma de despertar o interesse / gosto pelas narrativas que se utilizam do maravilhoso para problematizar e atender as demandas contemporâneas, entre elas, aquela que aponta para a urgência de se refletir acerca das conflituosas relações de gênero, que, de certa forma, vêm sendo alimentadas e fundamentadas pela forma como as mulheres têm sido retratadas na literatura, em especial, naquela destinada ao público infantojuvenil.

É nessa perspectiva que o presente trabalho se insere, ou seja, de valorização dessas produções literárias como fonte de conhecimento de contextos e formas de pensar de outros tempos e outros povos, mas também

\footnotetext{
1 As denominações contos de fadas e contos maravilhosos geralmente são usadas como equivalentes, no entanto, é possível afirmar que todo conto de fada é um conto 'maravilhoso', mas este nem sempre é um conto de 'fada'. Ambos têm em comum o encantamento. No sentido tradicional, o conto maravilhoso é uma narrativa que decorre em um espaço fora da realidade comum em que vivemos, e onde os fenômenos não obedecem às leis naturais que nos regem. No início dos tempos, o maravilhoso foi a fonte misteriosa e privilegiada de onde nasceu a Literatura (COELHO, 1982, p. 84-85).
} 
como possibilidade para desconstrução e reelaboração da imagem da mulher ${ }^{2}$ até chegar aos nossos dias, como o que acontece no conto "A moça tecelã", de Marina Colasanti $\left(1994^{3}\right)$. Desse modo, como forma de compreender as produções contemporâneas, procuramos lançar um olhar sobre os estudos desenvolvidos em torno da origem dos clássicos da Literatura Infanto-Juvenil, tomando como base, especialmente, o viés histórico-cultural dado por Coelho, por comungar do seu pensamento de que tal enfoque da literatura revela a importância que se atribui ao Passado ou às heranças deixadas pelas Tradições, como "chão" que nos servirá de base para as inovações do Presente, sem perder de vista o que se deseja construir para o Futuro. Um pensamento que coincide com a própria definição do contemporâneo apresentada por Giorgio Agamben (2009), como aquele que é "inatual", ou seja, aquele que mantém relação com o seu tempo, aderindo a este, mas dele tomando distância. Isso se confirma na afirmação da autora, para quem "os estudos de Literatura Infantil revelaram-se extremamente fecundos para abrir aos estudiosos da Literatura/Cultura de hoje os caminhos de conhecimento de ontem e, também, propiciar-lhes meios de compreenderem as inovações em curso que apontam para o amanhã em projeto." (COELHO, 2010, p. 11).

Vale ressaltar, no entanto, que ao se pensar em termos de passado, presente e futuro e de contexto histórico-cultural, não se pode perder de vista a mudança na regra do jogo. Alguns segmentos da sociedade que antes eram considerados excluídos são hoje os "novos atores sociais", que necessitam reconstruir uma história própria esquecida pelo discurso da comunidade hegemônica: as mulheres, os gays, os agrupamentos étnicos e religiosos, sem deixar de mencionar as mobilizações dos sem-teto ou o novo papel protagonista da terceira idade. Mudanças que ocorreram não só no campo das imagens, mas também nos campos político e econômico, as quais nos fazem pensar que estamos vivendo um tempo de "mutação civilizatória". Para o crítico uruguaio Hugo Achugar (2006, p. 154), todos nós estamos inseridos nesse processo de mutação, o que gera a angústia de não saber para onde vamos,

\footnotetext{
${ }^{2} \mathrm{~A}$ opção pelo uso do termo mulher se dá porque, apesar de hoje se utilizar preferencialmente o plural, mulheres, ao longo da história se construiu mesmo uma imagem singular, modelar de mulher.

${ }^{3}$ Originalmente o conto faz parte do livro Doze reis e a moça no labirinto do vento. Rio de Janeiro: Nórdica, 1985.
} 
nem qual a direção a ser tomada. São mudanças que tanto podem provocar entusiasmo quanto incertezas.

Conforme observa Nelly Novaes Coelho em sua obra $A$ Literatura Infantil: história, teoria, análise (1982, p. 88), o "problema 'mulher' é, também, um dos mais importantes para serem resolvidos (ou pelo menos, enfrentados...) pela literatura infantil, juvenil e adulta." Diante desse cenário, vale refletir se a valorização e emancipação da mulher - que no conto "A moça tecelã", de Marina Colasanti, e em tantas outras produções recentes ocupa uma posição de destaque - estão relacionadas mais a esse processo de mutação de que trata Achugar, que é próprio da contemporaneidade, ou se é fruto de uma mudança histórica por que passa a imagem da mulher na sociedade e, consequentemente, na literatura; ainda, se seria resultado das lutas feministas para se repensar o sexismo nos contos de fadas, assim como para se desconstruir aquilo que se estabeleceu como característica básica desse gênero literário, já que, conforme observa Stith Thompson, "por alguma razão para quem compõe contos populares é a mulher que, na família, é quase sempre escolhida para o papel de vilão" (apud TRAÇA, 1992, p. 534). Em suma, revisitamos a origem da construção da imagem da mulher nos contos maravilhosos, olhando para o passado, com os pés titubeantes, apoiadas num presente incerto, na esperança de que aquilo que se reflete aqui signifique algo para o futuro que está por se construir e que muito conta e espera do público hoje infanto-juvenil para sua plena realização.

\section{Da imagem negativa nas fontes orientais à imagem idealizada nas origens ocidentais}

Em seu Panorama Histórico da Literatura Infantil/Juvenil, Nelly Novaes Coelho (2010, p.5) chama a atenção para a necessidade de que as novas gerações tomem consciência da importância da Literatura no processo de "evolução" pelo qual a humanidade tem passado desde que iniciou sua trajetória, isso pelo menos no contexto do mundo ocidental. A estudiosa chama

\footnotetext{
4 Já houve quem descobrisse que 80 por cento dos papéis negativos nos contos de Grimm são desempenhados por personagens femininas (TRAÇA, 1992, p. 96).
} 
de "rastreamento" o estudo histórico-cultural que faz do surgimento da Literatura Infantil desde a sua "célula-máter: a Novelística Popular Medieval" com suas origens orientais e indo-europeias. Um "rastreamento" que buscaremos acompanhar para observar como a mulher tem sido retratada desde a "narrativa primordial", ou seja, a literatura folclórica ou popular transmitida oralmente através das gerações, até aquela que, posteriormente, passou a ser transmitida por meio da escrita, a partir do século XVII, vindo a se tornarem clássicos infantis (através do registro de compiladores cultos como La Fontaine, Perrault, Grimm e Andersen, sendo este último considerado também autor de diversos contos.).

Acredita-se que surgiu na Índia, por volta do séc. V a. C., Calila e Dimna $^{5}$, a coletânea das narrativas mais antigas que deram início à Literatura Popular europeia. No entanto, é possível que "certos papiros egípcios" (p.8), que datam de mil anos antes e que foram encontrados na Itália no séc. XIX apresentam episódios narrativos iguais aos de Calila e Dimna. O mesmo acontece com alguns contos de As Mil e uma Noites, do qual trataremos mais adiante, também de origem oriental, e que aparece tardiamente na Europa, cujas narrativas se assemelham com os relatos egípcios. Entre os motivos idênticos, está o argumento do conto "Dois irmãos", que traz na sua base a temática da mulher como traidora, capaz de levantar falsas acusações. No estudo que faz dos contos tradicionais, Câmara Cascudo apresenta uma síntese dessa antiquíssima narrativa de origem egípcia:

\begin{abstract}
Anepu e Batau, irmãos, moram juntos. Anepu é casado e sua mulher tenta seduzir Batau, que the resiste. A mulher de Anepu acusa o cunhado de violência. Anepu prepara-se para matar o irmão, mas este, avisado pelas bezerras de curral, foge. Anepu persegue-o, mas o deus Armachis, invocado por Batau, faz aparecer um rio entre os dois irmãos. Quando amanheceu o dia, Batau, o mais novo, disse ao mais velho que ia para a floresta dos cedros e deixaria sua alma numa flor, em cima de uma árvore. Se o cedro fosse derrubado e a flor caísse, ele morreria, e ensinou o processo para ressuscitá-lo. E separaram-se. Anepu matou sua mulher e ficou vivendo sozinho, com seus bois e seu campo. O deus solar Armachis falou ao deus Chnum
\end{abstract}

5 Embora o texto original em sânscrito não tenha sido localizado, tem sua existência comprovada na Índia, devido às várias traduções que foram feitas dele. De antiquíssima origem Calila e Dimna pode ser considerado um fabulário indiano-persa-sírio-árabe-hebráico-latinocastelhano que serviu de fonte à literatura ocidental. Por alguns é visto como um verdadeiro tratado de Política, já que a luta pelo poder é um dos temas principais, por outros como um exemplário de 'boa conduta' para viver bem (COELHO, 2010, p. 11). 
e este deu uma linda mulher a Batau, para que não continuasse solitário na floresta dos cedros. Um cacho do cabelo da mulher de Batau caiu no mar e foi perfumando as águas até o rio onde lavavam as roupas do faraó. Este, informado do estranho perfume, descobriu o cacho de cabelo e mandou procurar a dona. Depois de muita luta, veio a mulher de Batau para o faraó e contou como seu marido morreria. Cortaram o cedro, a flor caiu e Batau morreu. O irmão, sabendo, veio e procurou a flor da alma de Batau até que a encontrou. Colocou o corpo de Batau numa esteira e a flor num vaso com água de cevada. Depois pôs essa água na boca do irmão, que se ergueu, vivo. Batau transformou-se no novilho-sagrado, propriedade de Anepu. O faraó comprou o novilho-sagrado por muito ouro e o colocou num santuário. Quando a nova mulher do faraó foi visitar o novilho, este falou, exprobando-lhe o procedimento. A mulher pediu para ao faraó para comer o fígado do novilho-sagrado, e o faraó matou o touro, e a mulher comeu o fígado. No momento do sacrifício, duas gotas de sangue do novilho-sagrado caíram, e duas árvores nasceram. Quando a mulher veio repousar na sombra dessas árvores, elas falaram, censurando sua conduta. A mulher pediu que 0 faraó cortasse as árvores para fazer tábuas. Uma lasca feriu a mulher na boca. Ela ficou grávida e nasceu um príncipe. O faraó morreu e o príncipe subiu ao trono. Era Batau. Mandou julgar a mulher e puniu-a. O irmão, Anepu, foi feito Vice-Rei e substitui-o no governo do Egito (CASCUDO, 1946, p. 16-17).

Interessa-nos no extenso resumo apresentado acima, a fórmula que seria seguida por fabulistas e contistas pelo ocidente a fora: a mulher trai, a mulher merece morrer. No texto "Contribuições feministas para o estudo da violência de gênero", a professora Heleieth I. B. Saffioti realiza um estudo em que estabelece distinções entre as diferentes modalidades da violência de gênero e, de início, apresenta um conceito abrangente muito pertinente às discussões que se propõe na presente pesquisa:

Violência de gênero é o conceito mais amplo, abrangendo vítimas como mulheres, crianças e adolescentes de ambos os sexos. No exercício da função patriarcal, os homens detêm o poder de determinar a conduta das categorias sociais nomeadas, recebendo autorização ou, pelo menos, tolerância da sociedade para punir o que se Ihes apresenta como desvio. Ainda que não haja nenhuma tentativa, por parte das vítimas potenciais de trilhar caminhos diversos do prescrito pelas normas sociais, a execução do projeto de dominação-exploração da categoria social homens exige que sua capacidade de mando seja auxiliada pela violência. (SAFFIOTI, 2001, p. 115).

Passados 3.200 anos de sua criação, a história dos "Dois Irmãos" permanece viva, alimentando narrativas tradicionais tanto no Brasil, como é o caso da versão "A Princesa e o Gigante", quanto em Portugal, com o conto folclórico "Cravo, rosa e Jasmin". Há, ainda, o registro que o folclorista Aarne 
Thompson faz do conto "The Ogre's Heart in the egg", que apresenta boa parte dos motivos da versão egípcia e pertence "a um ciclo universal e existente em todos os folclores conhecidos desde a coleção de Grimm" (COELHO, 2010, p.21-22). Como se pode perceber, mudam os tempos, mas os motivos permanecem, pelos menos entre os folcloristas.

Outra coletânea, também de origem indiana, que serviu de fonte para a narrativa popular ocidental foi Sendebar ou o Livro dos enganos das mulheres ${ }^{6}$. Como o próprio título sugere a célebre coletânea foi também uma das responsáveis pela propagação "da imagem negativa da mulher, vista como astuta, mentirosa, traidora, ambiciosa... que mais tarde, na novelística ocidental, vai alternar com a imagem positiva da mulher-anjo, de inspiração cristã, dando origem à imagem dual que define a mulher até hoje, dentro da concepção cristã ocidental" (COELHO, 2010, p. 13). A obra tem como provável autor o filósofo indiano Sedabad, consta de 26 narrativas e apresenta uma estrutura em cadeia, assim como Calila e Dimna, ou seja, uma estória saindo de dentro da outra; forma que se vulgariza posteriormente através da coletânea de As Mil e Uma Noites". Em Sendebar, as narrativas "nascem e se entrelaçam" por meio de um argumento básico: uma madrasta acusa falsamente o filho de um rei de tentar violentá-la. O príncipe consegue provar sua inocência e a "madrasta mentirosa é morta, entregue às chamas" (MENÉNDEZ PELAGO apud COELHO, 2010, p. 13).

Também naquela que é considerada a mais célebre compilação de contos de origem oriental, As Mil e Uma Noites, já citada, o tema da violência contra a mulher está na base de suas narrativas, já que as narrativas surgem de ameaça de morte de um marido, o sultão, contra a mulher, Sherazade, que, para não morrer, todas as noites, a pedido de sua irmã Dinarzade, vai contando histórias que nunca têm fim, mantendo alerta a curiosidade do sultão, que a cada noite a vai poupando da morte para ouvir o resto das peripécias. No entanto, não se pode deixar de considerar que nessa narrativa a mulher tem poder de fala e mostra ter esperteza para sobreviver.

\footnotetext{
${ }^{6}$ Penetrou na Península Ibérica no século XIII, numa versão direta do árabe para o castelhano.

7 Somente no século XVIII, com a tradução de Galland para o francês e algumas adaptações, foi divulgada na Europa, nesse caso, não exerceu influência direta na novelística ocidental arcaica, como as outras coletâneas.
} 
Como podemos ver, o que as narrativas primordiais fazem nada mais é do que reproduzir a mentalidade patriarcal que sempre permeou a história da humanidade, uma história de sujeição da mulher, imposta pela intimidação; o que nunca faltou foi motivo ao longo dessa história para justificar que esta fosse atirada na fogueira. Conforme observa Rosa Montero, na Introdução do livro Histórias de mulheres, intitulada de "A vida invisível" (2007, p. 12-13),

\begin{abstract}
as mulheres foram cidadãs de segunda classe durante milênios, tanto no Oriente como no Ocidente, no Norte como no Sul. O infanticídio por sexo (matar as meninas recém-nascidas porque são uma carga indesejada, ao contrário do cobiçado varão) foi uma prática difundidíssima e em toda a história, desde os romanos até os chineses ou os egípcios, e até hoje ocorre mais ou menos abertamente em muitos países do chamado Terceiro Mundo. O que dá uma ideia do escasso valor que se atribuía à mulher, que já vinha ao mundo com o desconsolo fundamental de não haver sido sequer desejada.
\end{abstract}

Como a arte imita a vida, não é de se estranhar que "por alguma razão para quem compõe contos populares é a mulher que, na família, é quase sempre escolhida para o papel do vilão" (THOMPSON apud TRAÇA, 1992, p, 53). Possivelmente. pelo fato de que os autores dessas produções eram homens, em sua maioria.

Dados os traços comuns aos textos literários em questão até aqui, o que se percebe é que os relatos retratam os valores próprios de sociedades primitivas, com sua lógica fundamentada na lei do mais forte; uma forma de organização social rudimentar e hierarquizada, com classes rígidas e bem delimitadas: fortes e poderosos de um lado, fracos e desvalidos do outro. Não é difícil imaginar o (não) lugar da mulher nessa lógica. O maravilhoso aparece nas narrativas primitivas como uma tentativa de explicar o mundo pelo "pensamento mágico", já que não conseguiam ainda dominá-lo pelo conhecimento científico. No entanto, Coelho (1994, p. 16-17) defende que, mesmo com narrativas derivando da violência e nela desembocando, esses textos literários "toscos e rudimentares" que a Antiguidade Oriental transmitiu ao Ocidente podem registrar narrativas "edificantes", capazes de difundir modelos de moral que levem à atitude de respeito ao próximo, levando a um "convívio comunitário equilibrado, aspecto que será sobremaneira ampliado na 
literatura europeia que surge no período medieval". A violência, por exemplo, que no sistema primitivo era vista como natural, no humanismo é posta em questão.

Mas até lá precisamos compreender como surgiram as primeiras manifestações literárias no Ocidente Europeu, considerando que estas produções folclóricas mais tarde seriam transformadas em literatura infantil. Nos séculos medievais, compreendidos como o período que vai do século $\mathrm{V}$ ao $\mathrm{XV}$, circula nessa região uma vasta produção em prosa, sendo uma de cunho popular (exemplar), de fontes orientais ou greco-romanas, e outra de origem culta (aventuresca), que seriam de inspiração ocidental e corresponderiam às novelas de cavalaria. Enquanto a prosa narrativa exemplar retrata o cotidiano, o conhecimento de mundo e "valores de comportamento étnico-social", a prosa narrativa aventuresca retrata "um mundo de magia e de maravilhas", onde predomina um "idealismo extremo", distante de realidade (COELHO, 2010, p. 25).

Conhecido como período intermediário entre a civilização pagã e a civilização cristã, a Idade Média foi um período marcado pela "violência no convívio humano", marcado pelo dualismo de "forças selvagens, opostas e poderosas" que se chocaram em luta pelo poder. Nada mais natural do que encontrar as marcas dessa violência "impressas" nas produções artísticas que nasceram nessa época, entre elas, as narrativas maravilhosas. Conforme ressalta Coelho (2010, p. 29-30), "nos contos populares maravilhosos, o mundo feudal está representado em toda sua crueza", como acontece no argumento do marido que sacrifica brutalmente a esposa, por desejar a própria filha. Nos temas comuns à época, fieis às fontes orientais, imperam temáticas negativas, entre elas, a mulher como traidora é apontada de forma naturalizada como parte da "comédia humana de ontem e de hoje". Não é de se admirar, uma vez que a necessidade de colocar a mulher em uma situação de subjugação e de mantê-la sob controle é bem anterior a esse período.

Engels sustentava que a sujeição da mulher se originou ao mesmo tempo que a propriedade privada e a família, quando os humanos deixaram de ser nômades e se assentaram em povoados de agricultores. $\mathrm{O}$ homem, diz Engels, precisava assegurar-se filhos 
próprios, aos quais pudesse transferir suas posses, e por isso controlava a mulher (MONTERO, 2007, p. 10).

A intimidação alimentada pela desconfiança e estereótipo de traidora era uma forma de diminuir a força que advinha da "assombrosa capacidade" que as mulheres tinham pelo dom procriador. Além disso, acontece que antes dos grupos terem se tornado camponeses, ainda na vida "errante e caçadora", o valor de ambos os sexos era claramente definido e as funções eram consideradas igualmente valorosas e fundamentais: elas parindo, amamentando e criando; eles caçando e defendendo. Em contrapartida, com o surgimento da vida agrícola a função destinada ao homem deixou de ser específica, considerando que a mulher também podia cuidar da terra tanto ou melhor que ele, pois a fertilidade era uma "mágica" que conhecia e dominava bem. Nada mais natural do que ser considerada "demasiadamente poderosa" e de despertar medo e ânsia de controle por parte dos homens, que tinham a vantagem de serem mais fortes fisicamente (MONTERO, 2007, p. 10).

De acordo com Montero, o receio ante o poder feminino está retratado nas narrativas sobre a criação do mundo e nos primeiros mitos de nossa cultura. Nessas narrativas primordiais as mulheres são relegadas a um papel subsidiário e são apresentadas como "um ser débil, estouvado e carente de juízo"8. No entanto, a autora considera que essas narrativas acabam atribuindo "um papel agridoce mais imenso" às mulheres "como fazedoras da humanidade", ou seja, são elas que têm o "atrevimento de perguntar-se sobre o que existe além, o anseio de descobrir o oculto", desse modo, por sua curiosidade, que nada mais é do que "um ingrediente básico da inteligência", os males que Eva e Pandora trazem para o mundo são aqueles que formam a "substância do humano": o tempo, a enfermidade, e a mortalidade. Já, segundo a tradição judaica, a primeira mulher de Adão teria sido Lilith, e não Eva. Considerada a primeira feminista da história, Lilith reinvidicava os mesmos direitos de Adão; este, por meio da força física, tenta obrigá-la a obedecer, e

\footnotetext{
${ }^{8}$ Eva arruína Adão e toda a humanidade por deixar-se tentar pela serpente, e o mesmo faz Pandora, a primeira mulher segundo a mitologia grega, criada por Zeus para castigar os homens: o deus dá a Pandora uma ânfora cheia de desgraças, jarra que ela destampa, movida por sua irrefreável curiosidade feminina, liberando assim todos os males (MONTERO, 2007, p. 11).
} 
eis que ela o abandona. Certamente as desobediências de Lilith eram inaceitáveis para o deus patriarcal da época, que a transformou numa "diaba matadora de crianças", condenando à morte cem de seus filhos a cada dia; um castigo emblemático do "poder do macho sobre a fêmea" (MONTERO, 2007, p. 11).

De volta à Idade Média, vale observar a significativa alteração na forma como a mulher passou a ser retratada nas novas criações literárias ocidentais, entre elas, a novela de cavalaria, forma consagrada até hoje, seja na viva literatura de cordel nordestina, seja na renovação contínua nas diversas obras de literatura infantil ou juvenil. Pensada inicialmente como uma "expressão literária culta", as novas roupagens que foi ganhando através dos tempos fez desse, também conhecido como romance de cavalaria, "o mais popular dos gêneros medievais" (COELHO, 2010, p. 37). É de suma importância aos propósitos do presente trabalho, porque foi a partir dele que nasceram as fadas $^{9}$, responsáveis pela primeira construção positiva da imagem da mulher e do feminino na literatura. Uma construção que nada mais é do que o reflexo dos valores vividos no Ocidente cristão durante os séculos XII e XIII, período que coincide com o início do culto mariano; no nível religioso a mulher começa a ser valorizada pela Igreja de Roma, que a aproximava da Virgem Maria.

De acordo com Coelho (2010, p. 46), no nível literário, ao surgirem nas novelas de cavalaria, as fadas fariam parte de um "processo de valorização e idealização da Mulher, simbolizando-a como o ser ambíguo e misterioso que detém o poder sobre os destinos dos homens e se identifica com a própria vida". No entanto, embora no nível social essa idealização literária alimentasse na vida nos castelos aquilo que se convencionou chamar de "código do amor cortês", pressupondo uma submissão total do homem em relação à mulher, o que os registros históricos mostram é que no nível da vida concreta do dia a dia o respeito pela mulher era praticamente nulo. As relações de gênero que marcavam a vida nas cortes medievais "eram marcadas pela violência e pela

\footnotetext{
${ }^{9}$ Desde sempre a mulher teria representado no universo uma força primordial, tanto necessária quanto temida pelo homem. As fadas simbolizariam talvez a face positiva e luminosa dessa força feminina e essencial: o seu poder de dispor da Vida, de conter em si o futuro. É preciso lembrar que a principal missão das fadas nas histórias infantis é prever e prover o futuro de algum ser, já o reverso seria a bruxa, face frustradora, a mulher que corta o fio do destino, frustra a realização do ser (COELHO, 1982, p. 88).
} 
promiscuidade mais rude", e a mulher não passava de uma "peça útil ou inútil" na luta pelo poder.

Ainda assim, foram as atitudes idealizantes e aparentemente irreais da produção literária da época, marcada pela "vassalagem amorosa", atribuindo à mulher um "valor superior e precioso" a ser alcançado pelo homem que atuou profundamente na consciência dos povos, de modo a fazer com que a mulher passasse de

\begin{abstract}
objeto da ação alheia (como era desde a Antiguidade até fins da Idade Média) a sujeito consciente de seus próprios pensamentos, atos e responsabilidades perante a si mesma e perante a sociedade dos homens (como vem descobrindo o nosso século, mas cuja conscientização ainda está longe de ser atingida pela totalidade das mulheres). Nesse processo de conscientização, incluímos a descoberta da força secreta do feminino, que deve ser feita pela própria mulher, e que na literatura arcaica estaria simbolizada nas fadas. Note-se, pois, que vem de longe a imagem dual da mulher anjo ou demônio, que a tradição mantém até hoje. Desde cedo, através das mais inocentes estórias, as crianças, os meninos, as meninas e os jovens já vão assimilando essa interpretação polar da mulher (COELHO, 2010, p. 47).
\end{abstract}

\title{
Um breve olhar sobre os maravilhosos clássicas
}

Considerada uma categoria diferente entre os clássicos, as histórias populares a que se convencionou chamar de contos de fadas, mesmo não sendo encaradas por parte dos críticos e da academia com a "nobreza e prestígio" dedicada a obras que o cânone da literatura ocidental cunhou de "clássico", certamente, foram as que mais exerceram influência sobre a nossa cultura, assim como, foram as mais oferecidas às crianças. A falta de prestígio talvez esteja naquilo que Ana Maria Machado (2002, p. 35) chama "duplo preconceito" equivocado: por serem "histórias infantis" são consideradas sem importância ou por serem consideradas sem importância são dedicadas às crianças. O preconceito é explicado pelo fato de se tratar de uma criação de origem popular, no entanto, o que se percebe é que mesmo não tendo sido escritas com objetivo de alcançar o público infantil, já que este nem era notado quando surgiram os contos de fadas, "o alto nível de sua qualidade artística e a sua força cultural são atestados pela sua universalidade." E é em meio a essas contradições e paradoxos que surge o primeiro e mais clássico dos autores / 
compiladores de contos maravilhosos, Charles Perrault, aquele que se pretendia "poeta clássico", ao produzir Os Contos da Mãe Gansa, no século XVII, em pleno Renascimento / Classicismo, quando ainda não existia o gênero "literatura infantil", com o tempo, misteriosamente, faz sucesso e se imortaliza:

\begin{abstract}
A Bela Adormecida no Bosque, O Capuchinho Vermelho, Barba Azul, As fadas e Cinderela constituem o grupo de contos que se dirigem mais diretamente à mulher. No primeiro, se atentarmos nos dons das fadas, veremos a representação da mulher aristocrática: beleza, graça, temperamento angelical, habilidade para dançar na perfeição, uma voz de rouxinol e o sentido de música. O comportamento da heroína, tanto ao longo da primeira como da segunda parte, é de uma enorme docilidade, resignação e paciência, sublinhadas pela moralidade de Perrault. (TRAÇA, 1992, p. 93).
\end{abstract}

Nos contos clássicos, a condição feminina permanece inferior à masculina e mesmo parecendo incoerentes com a mentalidade contemporânea e com as mudanças ocorridas nos demais gêneros literários ao longo dos tempos, é inegável o poder de sedução que alguns contos de fadas exercem sobre os jovens leitores. Segundo Traça (1992, p. 91-92), as editoras não perdem de vista esse filão de venda garantida, publicando "as seleções e coleções de êxito mais fácil"; a autora é taxativa ao afirmar que "pais e professores, por desconhecimento, ignorância, preguiça, ou simples procura do que the é mais familiar, perpetuam a cadeia de imagens e modelos, sem levantarem grandes questões sobre a sua eficácia e coerência nos nossos dias”. Para Jack Zipes:

o modelo feminino elogiado por Perrault sublinha as qualidades de recato e paciência: o que quer dizer que a rapariga deve ficar passiva até que o homem 'que lhe convém' reconheça as suas virtudes e aceite casar com ela. $O$ homem age, a mulher espera. Ela deve reprimir os seus instintos e as suas pulsões e disfarçá-los em palavras convenientes, em gestos distintos, em roupas elegantes. Se é autorizada a exprimir-se, é para denotar a sua submissão" (apud TRAÇA, 1992, p. 93).

No fantástico-maravilhoso dos irmãos Grimm, produzido no século XIX, momento em que "a criança é descoberta", período intermediário entre o Romantismo e o Realismo, a mulher pode ser a "mediadora" em potencial do indivíduo "pobre ou plebeu" que quer ascender socialmente ao se casar com a "filha do rei"; pode ser aquela que consegue "desencantar os encantados", que 
têm o poder de gerar a vida, de colocar a vida em curso normal; precisa ser bela, pura, recatada, modesta, obediente e totalmente submissa ao pai, marido ou irmão:

\begin{abstract}
Cinderela triunfa graças à sua enorme bondade e paciência. As protagonistas de A Bela Adormecida e Branca de Neve são tão passivas, tão passivas que têm de ser trazidas de novo à vida por um homem. As inocentes heroínas de A Pequena Guardadora de Gansos e de Os Seis Cisnes são vítimas de mulheres calculistas e ambiciosas (TRAÇA, 1992, p. 95).
\end{abstract}

Ela pode tanto ser "a amada" por quem o príncipe luta para conquistar quanto apenas um "instrumento da procriação"; pode ser retratada como bondosa e amorosa, mas também como ardil e traiçoeira, sendo tanto motivo de salvação quanto de perdição para os homens, revelando a "ambiguidade da natureza feminina" que marcou as narrativas maravilhosas desde suas origens; pode, ainda, estar envolta em mistério e maldade como acontece com a figura das anciãs, vistas como velhas misteriosas, relacionadas como o diabo. No entanto, conforme observa Coelho (COELHO, 2010, p. 157-158), "os aspectos negativos da mulher aparecem basicamente em contos divertidos, isto é, são aspectos realçados como pilhéria; mulheres gulosas, perdulárias, teimosas, mentirosas, ignorantes, fingidas...”.

Também na obra de Andersen, contemporâneo dos Grimm, repetem-se aquelas que são apontadas como "virtudes básicas da mulher": submissão, obediência, recato, paciência, religiosidade. Não poderia ser diferente, já que em suas produções são retratados os valores ideológicos românticos e a mulher é vista como um ser dual. Uma visão que, como já pudemos ver, tem suas raízes na Idade Média, mas que é confirmada no Renascimento:

no plano do ideal, ela é o ser do qual depende a realização total do homem; no plano da realidade social e humana, é o ser-objeto, totalmente submisso à vontade do homem a quem pertence (pai, marido, irmão). Note-se, em todas as estórias que afirmam tal imagem da mulher, que sempre alguém decide seu destino sem consultá-la para nada: ela é totalmente passiva e a tudo se curva docilmente (COELHO, 2010, p. 162). 


\section{A mulher como protagonista: algumas considerações (longe de serem finais) sobre o maravilhoso contemporâneo}

Exaustivamente lido e analisado, "A moça tecelã", de Marina Colasanti (1994), é apenas um dos tantos contos maravilhosos que a autora produziu, mas já pode ser considerado, sem medo de errar, um clássico da Literatura Infanto-Juvenil Brasileira. A obra encanta leitores de todas as idades, justamente por tratar de uma temática complexa como a que envolve as relações de gênero numa "linguagem sublime", capaz de agradar / encantar e levar a uma necessária reflexão. Quando nos referimos ao sublime, pensamos na concepção latina da palavra, como a capacidade que determinados textos tem de agradar "[...] sempre e a todos", dispondo na alma "[...] sentimentos elevados" (LONGINO, 2005, p. 76-77), ou, ainda, na formulação moderna do sublime como o sentimento gerado pela associação dolorosa de cenas desagradáveis à primeira vista aos sentidos, mas que paulatinamente se transformam em deleite. Uma concepção que está estritamente vinculada ao conceito clássico de tragédia, pois se trata de um "[...] prazer advindo da pena e do temor" (ARISTÓTELES, 2005, p. 33).

No conto de Marina Colasanti, a mulher não só é protagonista da história, enquanto elemento diegético como personagem principal, em torno de quem gira o enredo, mas, principalmente, por ocupar uma posição de destaque em relação à figura masculina. A moça, de uma condição passiva, sobre quem um narrador onisciente narra uma história encantada, como tantas outras histórias de meninas, moças, damas, donzelas, princesas..., é ascendida a uma condição ativa, de quem, num sentido figurado, tece, e, num sentido literal, protagoniza, decidindo sobre sua vida, rompendo com o clássico final do casaram-se e foram felizes para sempre. Trata-se de uma produção capaz de cumprir a função da literatura de emancipar o leitor, de tirá-lo da zona de conforto dos paradigmas instituídos por uma sociedade patriarcal, que dita como ideal de felicidade para a mulher: o casamento e a companhia de um homem. Enquanto o casamento era a possibilidade para o desfecho bemsucedido nos contos clássicos, no contemporâneo o maravilhoso representa a liberdade de escolha que a mulher dos tempos (pós) modernos tem de optar 
por desconstruir/destecer aquilo the oprime, a solidão advinda da felicidade que o casamento e a companhia de um homem Ihe traria. O final do conto aponta para uma tendência na vida de boa parte das mulheres que, assim como a "moça" do conto em questão, optam por outro ideal de felicidade, o trabalho: "Tecer era tudo o que fazia. Tecer era tudo o que queria fazer" (COLASANTI, 1994, p. 44). Eis o seu desejo e realização.

A partir da nossa experiência de leitura e dos estudos de quem se propõe pesquisador/a da área de estudos literários, podemos afirmar que há nas produções contemporâneas, em especial, nos textos escritos por mulheres, incluindo as narrativas maravilhosas destinadas ao público infanto-juvenil, uma clara intenção de levantar uma discussão acerca das relações de gênero, bem como de desconstruir a imagem / o modelo de mulher pautado nas narrativas do clássico maravilhoso.

As reflexões que fundamentam as teorias feministas e os estudos de gênero defendem que, por possuírem "um núcleo de vivências específicas", as mulheres têm mais condições de retratar sentimentos e anseios fundamentalmente femininos. De acordo com Rosa Montero, no capítulo "Treze", do livro A louca da casa (2004, p. 126), durante milênios os homens construíram literariamente inúmeros modelos de mulher que na verdade "não correspondem a como nós somos, e sim a como eles nos veem, através das diversas fantasias do seu inconsciente: a mulher como perigo (a vampe que suga a energia e a vida do homem), a mulher terra-maga-mãe, a mulher menina-bonita-boboca estilo Marilyn...". A estudiosa defende que agora é a vez de as mulheres fazerem o mesmo, ou seja, botar para fora as suas "imagens míticas dos homens"; e questiona: "Eles nos veem assim, mas e nós como os vemos no nosso inconsciente? E que forma artística pode-se dar a esses sentimentos?"10. Pois bem, a imagem mítica do homem apresentada no conto de Marina Colasanti é de alguém invasivo, egoísta, ambicioso e manipulador. Vejamos: a moça, embora independente, capaz de prover tudo o que necessitava para uma vida tranquila, sentiu solidão, "e pela primeira vez pensou como seria bom ter um marido ao seu lado." Teceu o seu desejo e teve

10 Para Simone de Beauvoir, a "literatura infantil, mitologia, contos, narrativas, reflete os mitos criados pelo orgulho e pelos desejos dos homens: é através dos olhos dos homens que a rapariguinha explora o mundo e aí decifra o seu destino" (apud TRAÇA, 1992, p. 97). 
a privacidade invadida a partir do momento em que "o moço meteu a mão na maçaneta, [...] e foi entrando na sua vida." (p. 45)

Susan Moller Okin, em seu texto "Gênero, o público e o privado" (2008, p. 320), analisa um aspecto importante das relações de gênero que nos ajudarão a problematizar a discussão quando o que está em jogo é a privacidade da mulher. Diz respeito ao fato de que quando se pensa os conceitos de esfera pública e privada - e como vida privada se entende o âmbito do doméstico e, consequentemente, da família -, corre-se o risco de negligenciar a questão da violência sofrida pela mulher dentro da própria casa. Segundo a filósofa política, "a ideia liberal da não intervenção do Estado no âmbito doméstico, ao invés de manter a neutralidade, na verdade reforça as desigualdades existentes nesse âmbito", já que a privacidade na esfera doméstica tem forte influência da natureza patriarcal do liberalismo. Nesse sentido, as esposas são consideradas parte da privacidade do homem, da mesma forma que suas propriedades, e isso está retratado na história da "moça": enquanto ela pensou em filhos, por acreditar que isso aumentaria sua felicidade, ele "em nada pensou a não ser nas coisas todas" que o trabalho / tear da mulher poderia lhe dar. Aprisionada por ele na mais alta torre do palácio, que ela mesma construiu, "sem descanso tecia a mulher os caprichos do marido" (p. 45), confirmando um processo de hierarquia e dominação que alimentou as relações de gênero por milênios. Okin toma como base os estudos de Joan Scott para chamar a atenção para o fato de que é preciso enfrentar o desafio de "expor a construção social do gênero por meio de sua desconstrução." O que significaria, nas palavras de Scott,

[...] uma rejeição do caráter fixo e permanente da oposição binária, de uma historicização e de uma desconstrução genuínas dos termos da diferença sexual. [...] revertendo e deslocando sua construção hierárquica, em vez de aceitá-la como real ou auto-evidente ou como fazendo parte da natureza das coisas. É evidente que, num certo sentido, as/os feministas vêm fazendo isso por anos" (SCOTT, 1995).

De volta às pertinentes reflexões de Rosa Montero (2004, p. 123), esta afirma que embora se declare feminista e tenha apresentado argumentos de teor dualista ao sugerir uma espécie de revanche das mulheres em relação ao que os homens produziram sobre elas ao longo dos tempos, prefere se definir 
como antissexista, pois a palavra feminista pode apresentar ou ser compreendida num teor semântico equívoco, parecendo contrapor-se ao machismo, sugerindo uma supremacia da mulher sobre o homem. Na verdade, segundo a estudiosa, as correntes feministas não aspiram esse dualismo, "mas reivindicam exatamente o contrário: que ninguém se subordine a ninguém por causa do sexo, que o fato de termos nascido homem ou mulher não nos encerre num estereótipo". Deixa claro que sua preferência pelo termo antissexista não significa uma rejeição à palavra feminista, que mesmo sendo pouco precisa é "cheia de história e resume séculos e séculos de esforços de milhares de homens e mulheres que lutaram para mudar uma situação social aberrante".

Como pudemos ver até aqui, tal situação social pode ser problematizada na contemporaneidade por narrativas que se utilizam dos elementos que constituem essa "forma viva", comumente chamada de conto de fadas, mas que também pode ser considerado como próprio do conto, já que este, de acordo com Massaud Moisés (1985, p. 44), tem como característica básica uma "tensão poética que desencadeia no leitor sentimentos comovidos ou perplexos acerca da vida. Uma espécie de poesia das coisas, o enternecimento diante do reiterado esforço humano de superar os limites da própria condição". Certamente os jovens leitores e leitoras encontrarão na narrativa de Marina Colasanti o talento para colocar nas reduzidas páginas desse gênero literário os elementos capazes de levá-los ao "desenfado" e ao "deslumbramento", e de despertar o prazer pela leitura e pela reflexão acerca desses dramas humanos. Mas, principalmente, capazes de levá-los a novas formas de pensar as relações de gênero e a construir uma visão crítica acerca do mundo a sua volta.

\section{Referências}

ACHUGAR, Hugo. Planetas sem boca: escritos efêmeros sobre arte, cultura e literatura. Tradução Lyslei Nascimento. Belo Horizonte: Editora UFMG, 2006.

AGAMBEN, Giorgio. O que é o contemporâneo? e outros ensaios. Tradução Vinícius Nicastro Honesko. Chapecó, SC: Argos, 2009. 
ARISTÓTELES. Poética. In: A Poética Clássica. Tradução Jaime Bruna. São Paulo: Cultrix, 2005.

CASCUDO, L. Câmara. Contos Tradicionais do Brasil. Rio de Janeiro: Americ Ed., 1946.

COELHO, Nelly Novaes. A Literatura Infantil: história teoria, análise: das raízes orientais ao Brasil de hoje. São Paulo: Quíron / Global, 1982.

COELHO, Nelly Novaes. Panorama histórico da literatura infantil/juvenil: das origens indo-europeias ao Brasil contemporâneo. Barueri, SP: Manole, 2010.

COLASANTI, Marina. A moça Tecelã. In: LADEIRA, Julieta de Godoy (Org.) Contos Brasileiros Contemporâneos. São Paulo: Moderna, 1994.

LONGINO. Do Sublime. A Poética Clássica. Tradução Jaime Bruna. São Paulo: Cultrix, 2005.

MACHADO, Ana Maria. Como e por que ler os clássicos universais desde cedo. Rio de Janeiro: Objetiva, 2002.

MOISÉS, Massaud. A criação literária: prosa. São Paulo: Cultrix, 1979.

MONTERO, Rosa. A louca da casa. Rio de Janeiro: Ediouro, 2004.

MONTERO, Rosa. Histórias de mulheres - Introdução. A vida invisível. Trad. Joana Angélica D’Ávila Melo. Rio de Janeiro: Ed. Agir, 2007.

OKIN, Susan Moller. Gênero, o público e o privado. Trad. Flávia Biroli. Revista Estudos Feministas. Florianópolis, Vol 16 (2): 305-332. 2008.

SAFFIOTI, Heleieth. Contribuições feministas para o estudo da violência de gênero. Cadernos Pagu, n.16, p.115-136. 2001.

SCOTT, Joan. Gênero: uma categoria útil de análise histórica. In: Educação \& Realidade, 20(2): 71-79, jul/dez. 1995.

TRAÇA, Maria Emília. O fio da memória: Do Conto Popular ao conto para crianças. Porto Codex - Portugal: Porto Editora, 1992. 